\title{
Relationship of Adropin Level and Inducible Nitric Oxide Synthase with the Phases of Intestinal Ischemia-Reperfusion in Rats
}

\author{
DOAA A. ABD EL-MOETY, M.D.*; MAHMOUD M.A. ABUL-MEATY, M.D.* and \\ MAI M. ABD EL-WAHAB, M.D.** \\ The Departments of Physiology* and Pathology**, Faculty of Medicine, Zagazig University, Egypt
}

\begin{abstract}
Background: Adropin is a peptide hormone that plays an important role in energy homeostasis and endothelial functions. Nitric oxide is a potent vasodilator synthesized in the vascular endothelium from the Nitric Oxide Synthase enzyme (NOS). There are controversial studies about the role of NOS and its isoforms the endothelial (eNOS) and the inducible (iNOS) forms in Ischemia-Reperfusion (IR) injury. It was found that adropin influences gene expression of eNOS and enhances endothelial cell function. However, few researchers have studied the link between adropin and iNOS activity during different phases of IR-injury.
\end{abstract}

Aim of the Study: To estimate the plasma level of adropin, and iNOS activity and to study the relationship of both of them and their role during different phases of intestinal IRinjury in rats.

Material and Methods: A total of 20 rats were used in this study $(200-220 \mathrm{~g})$. Rats were divided into two groups (10 rats/each); group I (sham-operated group) and group II which exposed to laparotomy and occlusion of the superior mesenteric artery for $30 \mathrm{~min}$ the reperfusion for $60 \mathrm{~min}$. Serial blood samples were taken via an inserted carotid catheter at 0,30 , and $90 \mathrm{~min}$. Plasma levels of adropin and iNOS were measured by ELISA kits according to the manufacturer protocols. The contents of the intestinal lumen were centrifuged and examined for detection of hemoglobin and albumin concentrations. ANOVA with a post hoc test, independent sample $t$-test, and Person correlation were used for statistical analyses.

Results: Plasma adropin level and iNOS activity are significantly increased during ischemic and reperfusion phases of intestinal IR-injury when compared to the pre-ischemic phase of group II or when compared to the sham-operated group. Adropin was significantly correlated with iNOS during all phases. Moreover, unlike adropin, the iNOS level was correlated with the severity of the intestinal bleeding.

Conclusion: Plasma adropin level is positively correlated with iNOS activity during different phases of intestinal IRinjury in rats, and this may provide new markers for diagnosis of IR-injury during intestinal surgeries.

Correspondence to: Dr. Doaa A. Abd El-Moety, The Department of Physiology, Faculty of Medicine, Zagazig University, Egypt
Key Words: Adropin - iNOS - Intestinal ischemia-reperfusion.

\section{Introduction}

ADROPIN is a peptide hormone that was discovered in 2008 by Kumar et al., consists of 76 amino acids, and its amino acid sequence is identical in humans, mice, and rats [1]. This protein is encoded by the Enho gene, which is expressed primarily in the liver and the central nervous system [2] Moreover, adropin has been detected in various tissues and body fluids, such as the brain, cerebellum, liver, kidney, heart, pancreas, small intestine, endothelial cells, colostrum, and milk [1]. Adropin is involved in carbohydrate-lipid metabolism, metabolic diseases, central nervous system function, endothelial function and cardiovascular diseases [3].

Nitric Oxide (NO) plays a vital role in the circulation, especially the microcirculation due to its vasodilatory properties and its importance in maintaining and regulating blood flow in healthy tissues [4,5].

Controversial studies concerned with IschemiaReperfusion (IR) injury shed a light on the beneficial effects of Nitric Oxide Synthase (NOS) and its isoforms endothelial and inducible forms (eNOS) and (iNOS) respectively [6,7]. It has been reported that eNOS activity has a beneficial effect $[8,9]$ while, iNOS derived NO has a harmful effect $[10,11]$ on damaged tissue.

Adropin is one of the factors that affect endothelial function and eNOS activity [12]. It was found that adropin could be considered as a marker indicating endothelial dysfunction in patients with type 2 diabetes [13]. Moreover, it was found that adropin affects iNOS activity in the kidneys of rats 
with streptozotocin (STZ)-experimental induced diabetes [14].

So, this study was designed to elucidate the association of plasma adropin and iNOS activity and to study the relationship between their levels during different phases of IR-intestinal injury in a rat model.

\section{Material and Methods}

This study was performed on a total number of 20 adult male local strain albino rats, weighing 200-220gm, obtained from the Animal House of the Faculty of Veterinary Medicine, Zagazig University. Animals were kept in five clean cages, (40 $\mathrm{X} 28 \mathrm{X} 18 \mathrm{~cm}), 4$ rats per cage, under hygienic conditions in the Animal House of Faculty of Medicine, Zagazig University. This study was performed from May 2018 to July 2018. All animals received care in accordance with the guide to the care and use of experimental animals of the Institute of Laboratory Animal Resources [15]. All rats had free access to water and commercial rat standard chow that consisted of $25.8 \%$ protein, $62.8 \%$ carbohydrates and $11.4 \%$ fat [16]. Rats were kept at a comfortable temperature $\left(20-24^{\circ} \mathrm{C}\right)$ and were maintained on a normal light/dark cycle [17]

Rats were divided into two groups (10 rats per each group). Sham-operated group (Group I): Control group exposed to open laparotomy with exposure of superior mesenteric artery without occlusion. Intestinal ischemia-reperfusion group (Group II): Which was exposed to the clamping of the superior mesenteric artery then removal of the clamp for reperfusion.

\section{Surgical procedures:}

Anesthesia: After overnight fasting, the ketamine-xylazine mixture was used for anesthesia [18] . Ketamine $80 \mathrm{mg} / \mathrm{kg}$ and xylazine $12 \mathrm{mg} / \mathrm{kg}$ solution (Ketamine HCL/xylazine HCL solution, Catalogue No: MFCD00798875, Sigma-Aldrich) was injected by intra-peritoneal rout to induce a sufficient anesthesia/analgesia throughout the procedures.

Catheterization of the carotid artery: In the dorsal position, skin on the frontal aspect of the neck was shaved and sterilized with alcohol spray then a two-cm incision was made $2 \mathrm{~mm}$ right to the midline. Dissection of subcutaneous tissues without injury of the salivary gland was done, then the grove between the sternomastoid muscle and the trachea was gently dissected to reach the carotid sheath which gently opened and the right carotid artery which was identified by its pulsation was separated from the surrounding nerves then ligated by two ligatures by using 3/0 silk suture thread. The distal ligature was tightened while the proximal one remained loose. A Bulldog clamp was applied proximal to the proximal ligature for temporary occlusion of the artery until catheterization was completed. A small plastic strip was applied beneath the carotid artery to support it against a firm background during catheterization. By using an iris scissor, a half-cut was done in the wall of the carotid artery between the two ligatures, then the catheter (Carotid Catheter catalogue no CX-2012S, BASi Co, USA) was introduced inside the carotid and the proximal loose ligature was tightened over the catheter. Closure of the incision was done by $3 / 0$ silk while the hub of the catheter was connected to a syringe for the collection of serial blood samples [19]. Three samples (500 Neach) were collected from each rat in the group II; basal, ischemia, and reperfusion. The basal sample was collected just after the installation of the catheter in the carotid, the ischemia sample was collected at the end of the ischemic phase, while reperfusion was collected after 1 hour of reperfusion. In the sham-operated group, three samples were also taken at the equivalent time intervals after catheterization $(0,30, \& 90 \mathrm{~min})$ [20].

Intestinal ischemia-reperfusion: In dorsal position, $7 \mathrm{~cm}$ midline incision was done in the skin and muscles of the ventral abdominal wall then the area of the gastric bed was gently dissected to localize the Superior Mesenteric Artery (SMA) by being the pulsating branch from the abdominal aorta just cranial to the left renal artery. SAM was occluded my microvascular clamp for 30min then the clamp was removed and the reperfusion was allowed for $60 \mathrm{~min}$ [20]. The ischemia was confirmed by loss of pulsations in the branches of SMA in the mesentery while the reperfusion was marked by the immediate return of mesenteric pulsations after removal of the clamp. Regarding group I, no clamping of SMA was done.

Evaluation of Intestinal mucosal injury after reperfusion: After $60 \mathrm{~min}$ of reperfusion, $15 \mathrm{~cm}$ of small intestine was isolated and the luminal content was collected by irrigation of the intestinal lumen with $5 \mathrm{ml}$ of normal saline by using a syringe. The intestinal content was centrifuged and used for determination of albumin (as an indicator of intestinal permeability) and hemoglobin concentration (as an indirect measure of mucosal bleeding). An auto-analyzer (Fujifilm, Japan) was used for determination of albumin and hemoglobin concentrations [21]. 


\section{Blood sampling:}

Blood samples were collected in heparinized tubes, centrifuged for $15 \mathrm{~min}$ at $3000 \mathrm{rpm}$. The separated plasma was stored at $-20^{\circ} \mathrm{C}$ until the time of measurement.

\section{Biochemical analysis:}

Plasma levels of Adropin were measured by a quantitative sandwich ELISA kit [22] (MyBiosource, USA-Catalogue No MBS023874) according to the protocol described by the manufacturer. Plasma inducible nitric oxide synthase (iNOS) activity was determined by a quantitative sandwich ELISA kit [23] (Catalogue No MBS023874, MyBiosource, USA).

\section{Histopathology:}

The washed intestinal segment was stored in $10 \%$ formalin to be used for the pathology. The tissues were embedded in paraffin, sectioned at 5 a microtome, and stained with hematoxylin and eosin stain. Stained sections were examined under a light microscope (200x and 400x) equipped with a digital camera [24].

\section{Statistical analysis:}

The data obtained in the present study were expressed as mean \pm SD for quantitative variables and statistically analyzed according to the methods described by Kirkwood, (1985) [25]. The statistical analysis is done by using the SPSS program, version 23 (SPSS Inc. Chicago, IL, USA). Independent sample $t$-test was used to compare between group I and II, One-Way ANOVA [LSD (Post hoc)] test was used to compare statistical differences among basal, ischemic and reperfusion levels of adropin and iNOS. $p$-value $<0.05$ was considered statistically significant. Pearson's correlation analysis was performed to illustrate the relationship between plasma adropin and iNOS among different groups. Pearson's correlation was considered significant at $p$-values $<0.05$.

\section{Results}

As shown in (Table 1), albumin and hemoglobin level in intestinal lumen contents of group II were significantly higher than those in the sham-operated group $(p<0.001)$.

Table (1): Comparison of sham-operated rats and rats after intestinal ischemia-reperfusion.

\begin{tabular}{llll}
\hline \multicolumn{1}{c}{ Groups } & \multicolumn{1}{c}{$\begin{array}{c}\text { Group I } \\
(\mathrm{n}=10)\end{array}$} & $\begin{array}{c}\text { Group II } \\
(\mathrm{n}=10)\end{array}$ & $\begin{array}{c}p \text { - } \\
\text { value }\end{array}$ \\
\hline Parameters & $189.67 \pm 11.93$ & $185.83 \pm 13.39$ & $>0.05$ \\
Body weight $(\mathrm{g})$ & $0.45 \pm 0.12$ & $2.93 \pm 0.35$ & $<0.001$ \\
Int. Albumin (g/L) & $1.98 \pm 0.77$ & $<0.001$ \\
Int. hemoglobin (g/L) & $0.02 \pm 0.01$ & & \\
\hline
\end{tabular}

Regarding the difference of adropin level between group I and II, there was an insignificant change in the plasma adropin level, during the preischemia phase. However, the ischemia and the reperfusion phases showed significantly higher levels in group II than those in group I. Furthermore, in group II, it was evident that adropin level was increased to a very high level during ischemia and a similarly high level in the reperfusion phase (40.48 \pm 1.81 and $42.52 \pm 4.58$ respectively vs. $26.02 \pm$ $2.28 \mathrm{ng} / \mathrm{ml}, p<0.001$ vs. preischemia). Regarding group I, no significant changes were recorded during the three phases of the study (Table 2).

Table (2): Adropin level during phases of intestinal ischemiareperfusion in both study groups.

\begin{tabular}{|c|c|c|c|}
\hline $\begin{array}{l}\text { Plasma Groups } \\
\text { Adropin } \\
(\mathrm{ng} / \mathrm{ml})\end{array}$ & $\begin{array}{l}\text { Group I } \\
(\mathrm{n}=10)\end{array}$ & $\begin{array}{c}\text { Group II } \\
(\mathrm{n}=10)\end{array}$ & $\begin{array}{c}p \text {-value } \\
(t \text {-test })\end{array}$ \\
\hline $\begin{array}{l}\text { Pre-ischemia phase: } \\
\quad \mathrm{X} \pm \mathrm{SD} \\
p \text {-value of LSD }\end{array}$ & $26.10 \pm 1.44$ & $26.02 \pm 2.28$ & NS \\
\hline $\begin{array}{l}\text { Ischemia phase: } \\
\quad \mathrm{X} \pm \mathrm{SD} \\
p \text {-value of LSD }\end{array}$ & $\begin{array}{l}26.33 \pm 1.98 \\
\mathrm{NSa}\end{array}$ & $\begin{array}{l}40.48 \pm 1.81 \\
p<0.001^{\mathbf{a}}\end{array}$ & $p<0.001$ \\
\hline $\begin{array}{l}\text { Reperfusion phase: } \\
\quad \mathrm{X} \pm \mathrm{SD} \\
p \text {-value of LSD }\end{array}$ & $\begin{array}{l}25.79 \pm 2.11 \\
\text { NSa, NSb }\end{array}$ & $\begin{array}{l}42.52 \pm 4.58 \\
p<0.001 \mathbf{a}, \text { NSb }\end{array}$ & $p<0.001$ \\
\hline
\end{tabular}

a: Significant vs. preischemia phase.

b: Significant vs. ischemia phase.

Like adropin, the plasma level of iNOS was significantly higher in group II than in group I during both ischemia and reperfusion phases. Moreover, iNOS level showed significant increments during both ischemia and reperfusion phases in comparison to preischemic status in group II, while in group I no significant changes were reported (Table 3).

Table (3): The iNOS level during phases of intestinal ischemiareperfusion in both study groups.

\begin{tabular}{|c|c|c|c|}
\hline $\begin{array}{l}\text { Plasma Groups } \\
\text { iNOS } \\
\text { (U/L) }\end{array}$ & $\begin{array}{l}\text { Group I } \\
(n=10)\end{array}$ & $\begin{array}{c}\text { Group II } \\
(\mathrm{n}=10)\end{array}$ & $\begin{array}{c}p \text {-value } \\
(t \text {-test })\end{array}$ \\
\hline $\begin{array}{l}\text { Pre-ischemia phase } \\
\quad \mathrm{X} \pm \mathrm{SD} \\
p \text {-value of LSD }\end{array}$ & $6.32 \pm 0.83$ & $6.77 \pm 0.54$ & NS \\
\hline $\begin{array}{l}\text { Ischemia phase: } \\
\quad \mathrm{X} \pm \mathrm{SD} \\
p \text {-value of LSD }\end{array}$ & $\begin{array}{l}6.72 \pm 1.20 \\
\mathrm{NSa}\end{array}$ & $\begin{array}{l}8.87 \pm 0.94 \\
p<0.001 \mathbf{a}\end{array}$ & $p<0.05$ \\
\hline $\begin{array}{l}\text { Reperfusion phase: } \\
\quad \mathrm{X} \pm \mathrm{SD} \\
p \text {-value of LSD }\end{array}$ & $\begin{array}{l}6.65 \pm 0.34 \\
\mathrm{NSa}, \mathrm{NSb}\end{array}$ & $\begin{array}{l}9.42 \pm 0.73 \\
p<0.001^{\mathbf{a}}, \mathrm{NS} \mathbf{b}\end{array}$ & $p<0.001$ \\
\hline
\end{tabular}


Association between adropin and iNOS levels was demonstrated in Figs. (1-3). During the preischemia and ischemia phases, there was a significant positive correlation between adropin and iNOS levels ( $r=0.679, r=0.837$, respectively, $p<0.05$ ). This correlation was continuing even after reperfusion Fig. (3). The severity of intestinal mucosal injury denoted by the concentration of hemoglobin in the intestinal contents was also correlated significantly with iNOS level Fig. (4) rather than with adropin Fig. (5). This was not the case regarding albumin concentration in the intestinal contents as it showed an insignificant correlation with both adropin and iNOS $(r=0.543$, $r=0.404$, respectively, $p>0.05$ ).

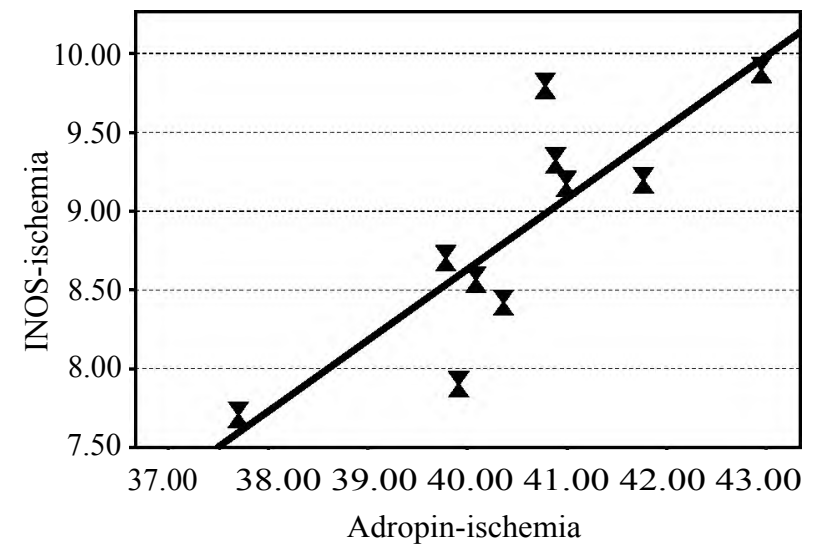

Fig. (2): Correlation between Adropin and iNOS levels during intestinal ischemia phase.

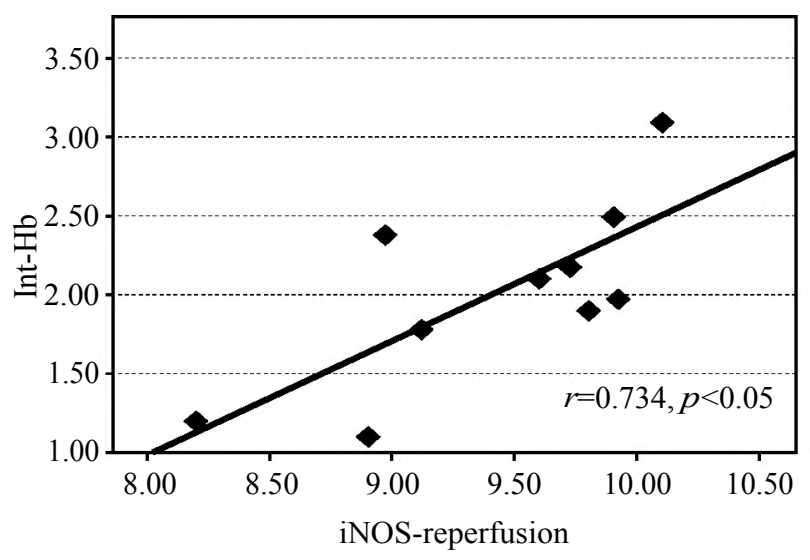

Fig. (4): Correlation of iNOS level and hemoglobin concentration in the intestinal contents of group II rats. (Int$\mathrm{Hb}$; Hemoglobin concentration in the intestinal contents).

The IR injury of intestine showed local histopathological changes in comparison to the shamoperated group. The intestinal changes were graded according to Quaedackers et al., [24]. The main

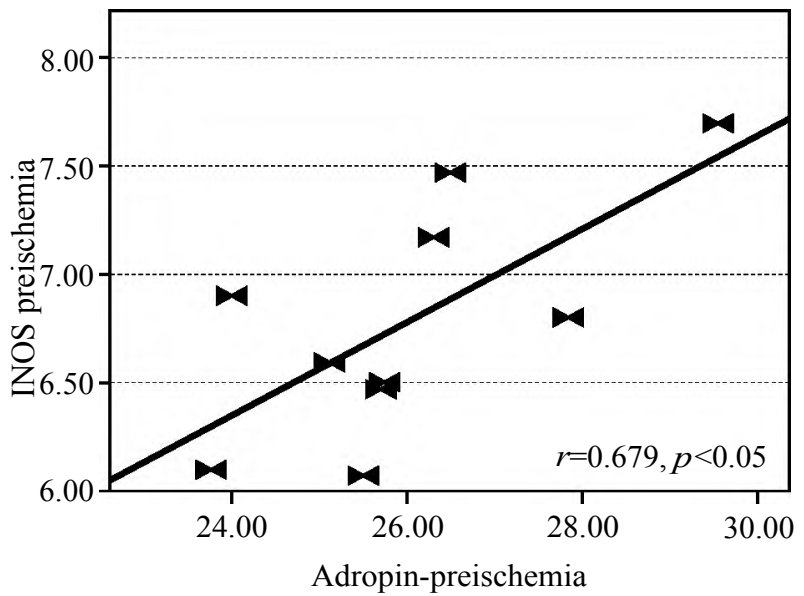

Fig. (1): Correlation between Adropin and iNOS levels during preischemia phase.

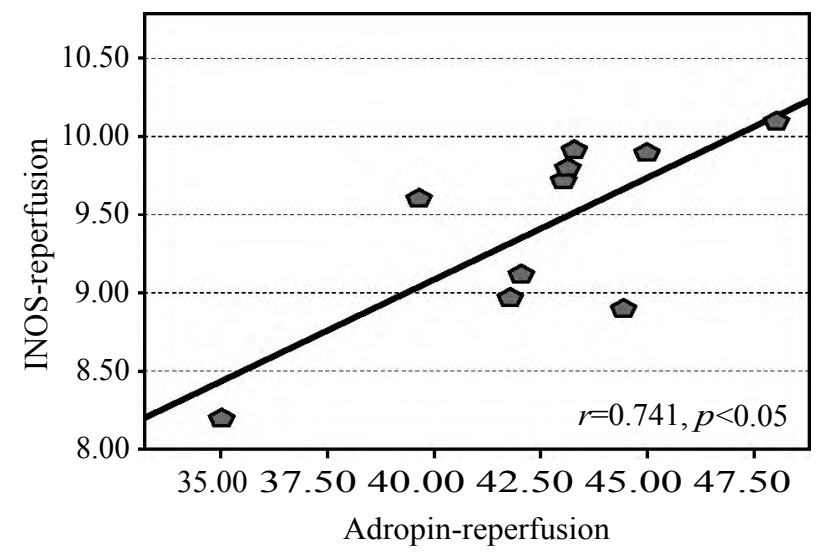

Fig. (3): Correlation between adropin and iNOS levels after reperfusion.

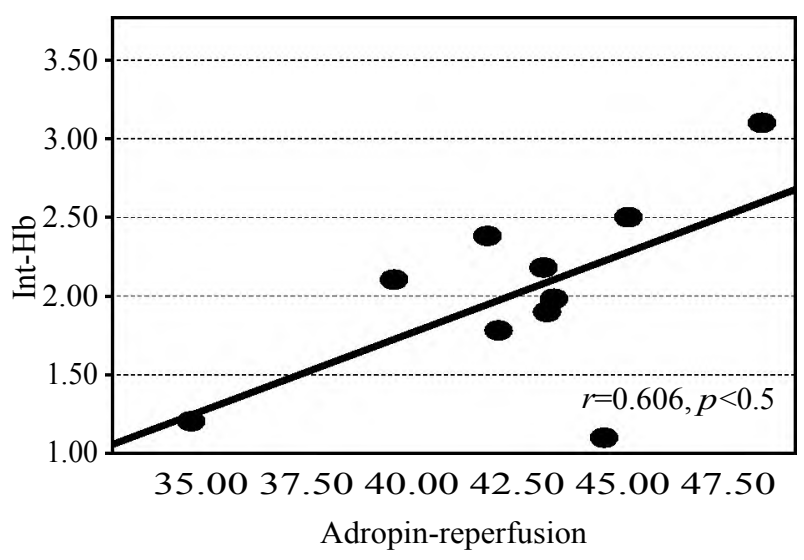

Fig. (5): Correlation of adropin level and hemoglobin concentration in the intestinal contents in group II. (Int-Hb; Hemoglobin concentration in the intestinal contents).

changes included the development of Gruenhagen's space at the tip of intestinal villi (Grade 2), dense inflammatory infiltrate (Grade 3 ) and complete destruction of the villi (Grade 4) Fig. (6). 

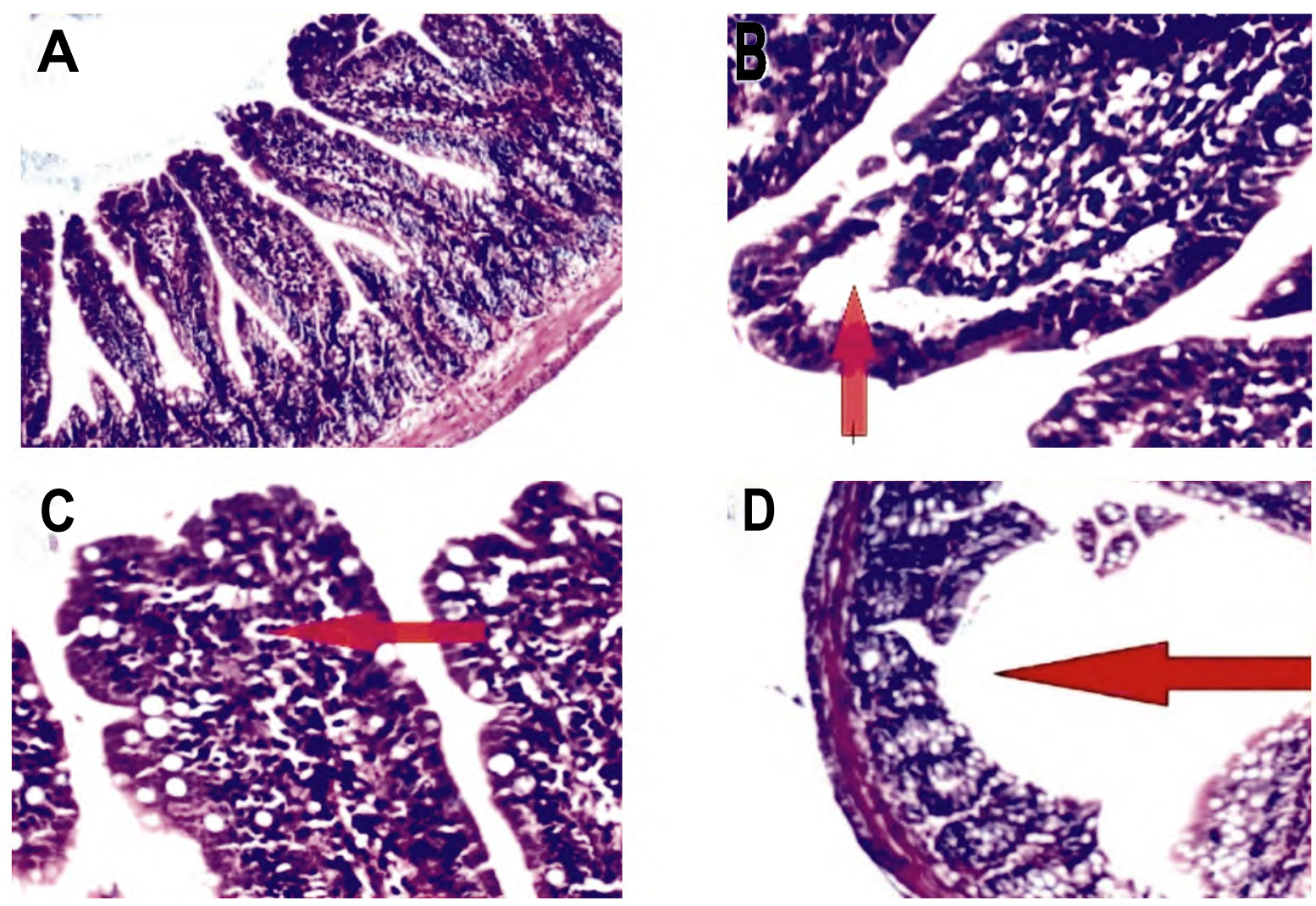

Fig. (6): Histopathological changes after intestinal Ischemia/Reperfusion (IR). (A): Normal intestinal mucosa and villi (H \& E X200). (B): Intestinal villi after IR showing the development of Gruenhagen's space at the tip of villi (Grade 2) (H \& E X400). (C): Intestinal villi after IR showing dense inflammatory infiltrate (Grade 3) (H \& E X400). (D): Intestine showing the destruction of the villi (Grade 4) (H \& E X200).

\section{Discussion}

Adropin is a peptide hormone involved in energy homeostasis and the control of glucose and fatty acid metabolism [3]. There are controversial studies about the physiological role of adropin in the cardiovascular system. The immunoreactivity of adropin has been detected in many tissues, including the heart [26]

Nitric Oxide (NO) is the most active vasodilator produced by endothelial cells. It is synthesized continuously from the amino acid L-arginine by Nitric Oxide Synthase (NOS) [27]. Additionally, it has been found that microcirculatory dysfunction usually associated with decreased production of NO [28]. Many studies concerned with increased impairment of microcirculatory function and tissue injury following NO inhibitory treatment shed a light on the importance of NO synthase (NOS) enzyme and its endothelial and inducible isoforms, eNOS and iNOS respectively [29].

Controversy about the prevention and treatment of ischemia reperfusion-injury have elucidated that
eNOS and iNOS activity leads to differences in NO production involving both positive and negative effects $[11,30]$. eNOS activity has a beneficial effect [8], while iNOS activity has a harmful effect [10] on damaged tissue.

This study created a rat model of intestinal ischemia-reperfusion. The success of this model in group II was proved by significant increases in levels of albumin and hemoglobin in the intestinal lumen [21], together with the pathognomonic features in Fig. (6). This study also revealed that there is no significant change in both plasma adropin level and plasma iNOS activity in rats of both groups during the pre-ischemic phase. However, a significant increase in their levels during both ischemic and reperfusion phases in group II in comparison to their levels in the group I was detected.

In addition, this study recorded changes in both plasma adropin level and plasma iNOS activity during different phases of ischemia-reperfusion injury. In group II, there was a significant elevation in both plasma adropin level and plasma iNOS 
activity in both ischemic and reperfusion phases compared to their levels during the pre-ischemic phase. However, the increments in both plasma adropin level and plasma iNOS activity were not furtherly increased during the reperfusion phase i.e. the means during reperfusion vs. the ischemic phase were insignificant in group II. Moreover, a significant positive correlation has been reported between plasma adropin level and iNOS activity in pre-ischemic, ischemic, and reperfusion phases in group II.

In agreement with these data, Altintas et al., [21] found that, adropin in blood-stream is markedly increased in rat model with cerebral ischemia induced by Middle Cerebral Artery Occlusion (MCAO) when compared to both sham-operated group and Ischemic Preconditioning (IPreC) group induced by intermittent left internal carotid artery occlusion, and there was no significant change in adropin level between sham and IPreC groups. They explained their findings as adropin expression in brain tissues is increased in case of ischemia resulted from MCAO to modulate energy homeostasis, and ischemic injury of neurons releases adropin into blood-stream. Adropin level was not changed in IPreC group when compared to control. As this state resulted in subclinical cerebral insufficiency that induces cerebrovascular adaptations as a neuroprotective stress defense mechanism increasing the durability of neurons and reducing the infarction size. So, neurons didn't release adropin into bloodstream [31].

Moreover, in Myocardial Infarction (MI) induced by administration of isoproterenol in rats, adropin synthesis in the hearts of rats was progressively increased $1-24 \mathrm{~h}$ after MI, and serum adropin level increased at 30 minutes after a heart attack and peaked at 2 hours. As, when myocardial cells become damaged, adropin is released into the bloodstream. So, a gradual increase in serum adropin could be a novel diagnostic marker in MI [32] Also, adropin level increases with the severity of heart failure [33].

On the other hand, serum adropin level was significantly lower in patients with acute MI compared to patients with stable coronary artery disease and healthy persons. Adropin may be considered as an independent early predictor of acute $\mathrm{MI}$ in patients with coronary artery disease [34]. Other studies have shown that a lower concentration of adropin is a risk factor for the development of coronary heart disease [35] and an independent factor for late saphenous vein graft occlusion [36]
It was reported that low circulating levels of adropin are associated with cardiac syndrome $\mathrm{X}$ that is related to endothelial dysfunction. In addition, higher levels of adropin protect the endothelium and prevent the development of this disease [37].

Concerning iNOS, the results of this study confirmed the positive correlation between iNOS and the severity of intestinal mucosal bleeding Fig. (4). This is supported by the findings of hightower and intaglietta [38] who found that the production of iNOS markedly increased during ischemiareperfusion injury of vascular endothelium and surrounding tissue cells and these high levels of microvascular iNOS worsen all IR injuries. However, continuous wave diagnostic frequency ultrasound exposure of IR-injury induced tissue damage resulted in inhibition of iNOS production during early perfusion and increased eNOS level during late perfusion providing protection for damaged tissues from IR-injury [38] .

Moreover, Busse et al., [39] and Kessler et al., [40] observed that low-grade vascular inflammation activates the production of iNOS isoform which considered as one of the major sources of oxidative stress generating Reactive Oxygen Species (ROS) $[41,42]$ and produces endothelial dysfunction $[43,44]$ Also, Jiang et al., [45] and Vinas et al., [46] found that the upregulation of iNOS and or NO synthesis through the iNOS pathway induced apoptosis during in vitro and in vivo ischemia-reperfusion studies, respectively. In addition, genetic manipulation that inhibits the production of iNOS [11] and treatment with specific iNOS inhibitors $[4 \mathbf{4 7 , 4 8}]$ during IR results in decreased injury and improved recovery. However, there were controversial studies supporting the benefit of iNOS [49-51].

Taken together, it is clear that in case of IRinjury the accelerated production of Reactive Oxygen Species (ROS) [52], and the cytokines released as a result of inflammatory process are involved in the pathogenesis of IR-injury [53]. The ROS and cytokines increase expression of iNOS in the vascular endothelium and induce the production of iNOS-derived NO which is not present in normal conditions and greatly harmful to the vascular endothelium [54], because the ROS interact with iNOS-derived NO leading to loss of its bioavailability and producing the reactive nitrogen species peroxynitrite that greatly interferes with the vascular signaling pathways [55]

About the positive correlation between adropin and iNOS activity in pre-ischemic, ischemic, and 
reperfusion phases of IR-injury in this study, this can be approved by [12] who reported that adropin is one of the factors that affect endothelial function and endothelial Nitric Oxide Synthase (eNOS) activity. Also, adropin regulate the bioavailability of nitric oxide through affecting gene expression of eNOS [56,57]. In addition, Aydin and Kuloglu [14] demonstrated that adropin altered iNOS expression. As they observed that in STZexperimental induced diabetes in rats, both adropin and iNOS showed elevated levels in renal tissues of rats.

Discrepancies in these data and others may be related to the difference in species: Human or animal model, the difference in study design and duration of the experiment, difference in kits, and the rapidity of ischemia development.

\section{Conclusion:}

Plasma adropin level and iNOS activity are significantly higher during the ischemic phase when compared to the pre-ischemic phase of IRintestinal injury in a rat model. Moreover, after reperfusion, adropin level and iNOS activity did not return to basal level but still significantly higher than pre-ischemic phase, but insignificantly higher than ischemic phase. This may be due to the release of adropin into the bloodstream from the damaged ischemic tissue and the activation of production of iNOS as one other major sources of oxidative stress during IR-injury.

In addition, there is a significant positive correlation between adropin and iNOS in group II during all phases of IR-injury, and this may provide an evidence about the link between adropin and iNOS and their role during different phases of IRinjury.

\section{References}

1- KUMAR K.G., TREVASKIS J.L., LAM D.D., SUTTON G.M., KOZA R.A., CHOULJENKO V.N., KOUSOULAS K.G., ROGERS P.M., KESTERSON R.A., THEARLE M., FERRANTE A.W. Jr., MYNATT R.L., BURRIS T.P., DONG J.Z. and HALEM H.A.: Identification of adropin as a secreted factor linking dietary macronutrient intake with energy homeostasis and lipid metabolism. Cell. Metab., 8: 468-81, 2008

2- GAO S., MCMILLAN R.P., JACAS J., ZHU Q., LI X., KUMAR G.K., CASALS N., HEGARDT F.G., ROBBINS P.D., LOPASCHUK G.D., HULVER M.W. and BUTLER A.A.: Regulation of substrate oxidation preferences in muscle by the peptide hormoneadropin. Diabetes, 63 : 3242-52, 2014.

3- GAO S., MCMILLAN R.P., ZHU Q., LOPASCHUK G.D., HULVER M.W. and BUTLER A.A.: Therapeutic effects of adropin on glucose tolerance and substrate utilization in diet-induced obese mice with insulin resistance. Mol Metab., 4: 310-24, 2015.

4- STEINER D.R., GONZALEZ N.C. and WOOD J.C.: Interaction between reactive oxygen species and nitric oxide in the microvascular response to systemic hypoxia. J. Appl. Physiol., 93 (4): 1411-8, 2002.

5- HURT K.J., MUSICKI B., PALESE M.A., CRONE J.K., BECKER R.E., MORIARITY J.L., SNYDER S.H. and BURNETT A.L.: Akt-dependent phosphorylation of endothelial nitric-oxide synthase mediates penile erection. Proc. Natl. Acad. Sci. U.S.A., 99 (6): 4061-6, 2002.

6- PUDUPAKKAM S., HARRIS K.A., JAMIESON W.G., DEROSE G., SCOTT J.A., CARSON M.W., SCHLAG M.G., KVIETYS P.R. and POTTER R.F.: Ischemic tolerance in skeletal muscle: Role of nitric oxide. Am. J. Physiol., 275 (1 pt2): H94-9, 1998.

7- SHARP B.R., JONES S.P., RIMMER D.M. and LEFER D.J.: Differential response to myocardial reperfusion injury in enos-deficient mice. Am. J. Physiol. Heart Circ. Physiol., 282 (6): H2422-H6, 2002.

8- CHANG W.L., CHUNG C.H., WU Y.C. and SU M.J.: The vascular and cardioprotective effects of liriodenine in ischemia-reperfusion injury via no-dependent pathway. Nitric. Oxide., 11 (4): 307-15, 2004.

9- HINES I.N., HARADA H., FLORES S., GAO B., MCCORD J.M. and GRISHAM M.B.: Endothelial nitric oxide synthase protects the post-ischemic liver: Potential interactions with superoxide. Biomed Pharmacother., 59 (4): 183-9, 2005.

10- GUNNETT C.A., LUND D.D., MCDOWELL A.K., FARACI F.M. and HEISTAD D.D.: Mechanisms of inducible nitric oxide synthase-mediated vascular dysfunction. Arterioscler. Thromb. Vasc. Biol., 25 (8): 1617-22, 2005.

11- QI W.N., CHEN L.E., ZHANG L., EU J.P., SEABER A.V. and URBANIAK J.R.: Reperfusion injury in skeletal muscle is reduced in inducible nitric oxide synthase knockout mice. J. Appl. Physiol., 97 (4): 1323-8, 2004.

12- SENA C.M., PEREIRA A.M. and SEIÇA R.: Endothelial dysfunction-a major mediator of diabetic vascular disease. Biochim. Biophys. Acta., 1832: 2216-31, 2013.

13- TOPUZ M., CELIK A., ASLANTAS T., DEMIR A.K., AYDIN S. and AYDIN S: Plasma adropin levels predict endothelial dysfunction like flow-mediated dilatation in patients with type 2 diabetes mellitus. J. Investig. Med., 61: 1161-1164. 2013

14- AYDIN S. and KULOGLU T.: Immunohistochemical expressions of adropin and inducible nitric oxide synthase in renal tissues of rats with streptozotocin-1nduced experimental diabetes. Biotech. Histochem., 89 (2): 104-10, 2014.

15- Institute of Laboratory Animal Resources, Commision On Life Sciences and National Research Council: Guide for the care and use of laboratory animals, 8 thEdition. National academy press, Washington DC, 21-55, 1996.

16- AHREN B. and SCHEURINK A.J.: Marked hyperleptinaemia after high fat diet associated with severe glucose intolerance in mice. Eur. J. Endocrinal., 139 (4): 461-7, 1998 
17- LESOURD B. and MAZARI L.: Nutrition and immunity in the elderly. Proceedings in the Nutrition., 58: 685-95, 1999.

18- RITSCHL L.M., FICHTER A.M., HABERLE S., VONBOMHARD A., MITCHELL D.A., WOLFF K.D. and MUCKE T.: Ketamine-Xylazine Anesthesia in Rats: Intraperitoneal versus Intravenous Administration Using a Microsurgical Femoral Vein Access. J. Reconstr. Microsurg., 31 (5): 343-7, 2015.

19- FENG J., FITZ Y., LI Y., FEMANDEZ M., PUCH I.C., WANG D., PAZNIOKAS S., BUCHER B., CUI X. and SOLOMON S.B.: Catheterization of the Carotid Artery and Jugular Vein to Perform Hemodynamic Measures, Infusions and Blood Sampling in a Conscious Rat Model. J. Vis. Exp., 95: e51881, doi: 10.3791/51881. 2015.

20- SALEH H. and EL-SHORBAGY H.M.: Mechanism underlying methyl eugenol attenuation of intestinal ischemia/ reperfusion injury. Applied Physiology, Nutrition, and Metabolism., 42: 1097-105, 2017.

21- NAITO Y., KATADA K., TAKAGI T., TSUBOI H., KURODA M., HANADA O., KOKURA S., YOSHIDA N., ICHIKAWA H. and YOSHIKAWA T.: Rosuvastatin reduces rat intestinal ischemia-reperfusion injury associated with the preservation of endothelial nitric oxide synthase protein. World J. Gastroenterol., 7; 12 (13): 2024-30, 2006.

22- AYDIN S., EREN M.N., KULOGLU T., AYDIN S., YILMAZ M., GUL E., KALAYCI M., YEL Y., CAKMAK T. and BICO S.: Alteration of serum and cardiac tissue adropin, copeptin, irisin and TRPM2 expressions in DOX treated male rats. Biotech. Histochem., 90 (3): 197-205, 2015.

23- AKCILAR R., AKCILAR A., SIMSEK H., KOCAK F.E., KOCAK C., YUMUN G. and BAYAT Z.: Hyperbaric oxygen treatment ameliorates lung injury in paraquat intoxicated rats. Int. J. Clin. Exp. Pathol., 8 (10): 1303442, 2015.

24- QUAEDACKERS J.S., BEUK R.J., BENNET L., CHARLTON A., OUDE EQBRINK M.G., GUNN A.J. and HEINEMAN E.: An evaluation of methods for grading histologic injury following ischemia/reperfusion of the small bowel. Transplant Proc., 32 (6): 1307-10, 2000.

25- KIRKWOOD B.R.: Essential medical statistics. Statistics in Medicine, 8 (5): 636-41, 1989

27- AYDIN S., KULOGLU T., AYDIN S., EREN M.N., YILMAZ M., KALAYCI M., SAHIN I., KOCAMAN N., CITIL C. and KENDIR Y.: Expression of adropin in rat brain, cerebellum, kidneys, heart, liver, and pancreas in streptozotocin-induced diabetes. Mol. Cell. Biochem., 380: 73-81, 2013.

28- TOUSOULIS D., KAMPOLI A.M., TENTOLOURIS C., PAPAGEORGIOU N. and STEFANADIS C.: The role of nitric oxide on endothelial function. Curr. Vasc. Pharmacol., 10: 4-18, 2012.

29- KUROSE I., WOLF R., GRISHAM M.B., AW T.Y., SPECIAN R.D. and GRANGER D.N.: Microvascular responses to inhibition of nitric oxide production: Role of active oxidants, Circ. Res., 76 (1): 30-9, 1995.

30- NAGASE S., ISOBE H., AYUKAWA K., SAKAI H. and NAWATA H.: Inhibition of nitric oxide production in- creases dimethylnitrosamine-induced liver injury in rats. J. Hepatol., 23 (5): 601-4, 1995.

31- BERTUGLIA S. and GIUSTI A.: Microvascular oxygenation and oxidative stress during postischemic reperfusion. Po2, ros, and no during reperfusion. Adv. Exp. Med. Biol. 566: 23-9, 2005.

32- ALTINTAS O., KUMASB M. and ALTINTAS M.O.: Neuroprotective effect of ischemic preconditioning via modulatingthe expression of adropin and oxidative markers against transientcerebral ischemia in diabetic rats. Peptides., 79: 31-8, 2016.

33- AYDIN S., KULOGLU T., AYDIN S., KALAYCI M., YILMAZ M., CAKMAK T. and EREN M.N.: Elevated adropin: A candidate diagnostic marker for myocardial infarction in conjunction with troponin-I. Peptides, 58 : 91-7, 2014.

34- LIAN W., GU X., QIN Y. and ZHENG X.: Elevated plasma levels of adropin in heart failure patients. Intern. Med., 50: 1523-7, 2011 .

35- YU H.Y., ZHAO P., WU M.C., LIU J. and YIN W.: Serum adropin levels are decreased in patients with acute myocardial infarction. Regul. Pept., 190-91: 46-9, 2014.

36- ZHANG C., ZHAO L., XU W., LI J., WANG B., GU X. and CHEN. J.: Correlation of serum adropin level with coronary artery disease. Zhonghua Yi XueZa Zhi., 94: $1255-7,2014$

37- DEMIRCELIK B., CAKMAK M., NAZLI Y., GUREL O.M., AKKAYA N., CEᄀTIN M., CETIN Z., SELCOKI Y., KURTUL A. and ERYONUCU B.: Adropin: A new marker for predicting late saphenous vein graft disease after coronary artery bypass grafting. Clin. Invest. Med., 37: E338-E344, 2014.

38- CELIK A., BALIN M., KOBAT M.A., ERDEM K., BAYDAS A., BULUT M., ALTAS Y., AYDIN S. and AYDIN S: Deficiency of a new protein associated with cardiac syndrome X; called adropin. Cardiovasc. Ther., 31: 1748, 2013.

39- HIGHTOWER C.M. and INTAGLIETTA M.: Early iNOS Impairment and Late eNOS Enhancement during Reperfusion following $2.49 \mathrm{MHz}$ Continuous Ultrasound $\mathrm{Ex}$ posure after Ischemia. Ultrason. Sonochem., 16 (1): 197203, 2009.

40- BUS SE R. and MULSCH A: Induction of nitric oxide synthase by cytokines invascular smooth muscle cells. FEBS Lett., 275: 87-90, 1990.

41- KESSLER P., BAUERSACHS J., BUSSE R. and SCHINIKERTH V.B.: Inhibition of induciblenitric oxide synthase restores endothelium-dependent relaxations in proinflammatorymediator-induced blood vessels. Arterioscler Thromb. Vasc. Biol., 17: 1746-55, 1997.

42- SCHWEDLER S.B., KUHLENCORDT P.J., PONNUSWAMY P.P., HATIBOGLU G., QUASCHNING T. WIDDER J., WANNER C., POTEMPA L.A. and GALLE J.: Native C-reactive proteininduces endothelial dysfunction in ApoE (-/-) mice: Implications for iNOSand reactive oxygen species. Atherosclerosis, 195 (2): e76-e84, 2007.

43- XIA Y., ROMAN L.J., MASTERS B.S. and ZWEIERJ L. :Inducible nitric-oxide synthasegenerates superoxide from the reductase domain. J. Biol. Chem., 273: 226359,1998 . 
44- ROSS R.: Atherosclerosis-an inflammatory disease. N. Engl. J. Med., 340: 115-26, 1999.

45- LERMAN A. and ZEIHER A.M.: Endothelial function: Cardiac events. Circulation, 111: 363-8, 2005.

46- JIANG H., KOUBI D., ZHANG L., KUO J., RODRIGUEZ A.I., HUNTER T.J., GAUTAM S.C. and LEVINE R.A.: Inhibitors of inos protects pc 12 cells against the apoptosis induced by oxygen and glucose deprivation. Neurosci. Lett., 375 (1): 59-63, 2005.

47- VINAS J.L., SOLA A., GENESCA M., ALFARO V., PI F. and HOTTER G.: No and nos isoforms in the development of apoptosis in renal ischemia/reperfusion. Free Radic. Biol. Med., 40 (6): 992-1003, 2006.

48- ITO Y., ABRIL E.R., BETHEA N.W. and MCCUSKEY R.S.: Role of nitric oxide in hepatic microvascular injury elicited by acetaminophen in mice. Am. J. Physiol. Gastrointest. Liver Physiol., 286 (1): G60-G67, 2004.

49- ZHANG L., LOONEY C.G., QI W.N., CHEN L.E., SEABER A.V., STAMLER J.S. and URBANIAK J.R.: Reper fusion injury is reduced in skeletal muscle by inhibition of inducible nitric oxide synthase. J. Appl. Physiol., 94 (4): 1473-8, 2003.

50- ARNAUD C., GODIN-RIBUOT D., BOTTARI S., PEINNEQUIN A., JOYEUX M., DEMENGE P. and RIBUOT C.: Inos is a mediator of the heat stress-induced preconditioning against myocardial infarction in vivo in the rat. Cardiovasc. Res., 58 (1): 118-25, 2003.

51- LI Q., GUO Y., TAN W., STEIN A.B., DAWN B., WU W.J., ZHU X., LU X., XU X., SIDDIQUI T., TIWARI S. and BOLLI R.: Gene therapy with inos provides longterm protection against myocardial infarction without adverse functional consequences. Am. J. Physiol. Heart Circ. Physiol., 290 (2): H584-H589, 2006.

52- GRANGER N. and KVIETYS P.R.: Reperfusion injury and reactive oxygen species: The evolution of a concept. Redox. Biol., 6: 524-51, 2015.

53- ENTMAN M.L. and SMITH C.W.: Postreperfusion inflammation: A model for reaction to injury in cardiovascular disease. Cardiovasc. Res., 28: 1301-11, 1994.

54- AIRES R.D., CAPETTINI L.S., SILVA J.F., RODRIGUESMACHADO M.G., PINHO V., TEIXERIA M.M., CORTES S.F. and LEMOS V.S.: Paraquat poisoning induces TNF- $\alpha$-dependent iNOS/NO-mediated hyporesponsiveness of the aorta to vasoconstrictors in rats. PLoS One, 8: e73562, 2013.

55- KERR S., BROSNAN M.J., McINTYRE M., REID J., DOMINICZAK A. and HAMILTON C. Superoxide anion production is increased in a model of genetic hypertension. Hypertension, 33: 1353-8, 1999.

56- TRIBL B., BATEMAN R.M., MILKOVICH S., SIBBALD W.J. and ELLIS C.G.: Effect of nitric oxide on capillary hemodynamics and cell injury in the pancreas during pseudomonas pneumonia-induced sepsis. Am. J. Physiol. Heart Circ. Physiol., 286 (1): H340-H345, 2004.

57- LOVREN F., PAN Y., QUAN A., SINGH K.K., SHUKLA P.C., GUPTA M., AL-OMRAN M., TEOH H. and VERMA S.: Adropin is a novel regulator of endothelial function. Circulation, 122: S 185-S92, 2010. 


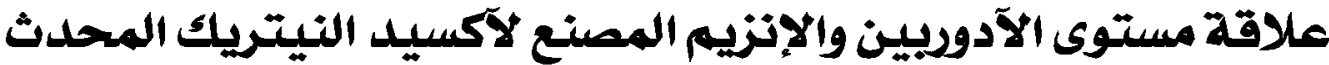

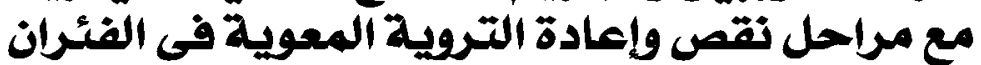

خلفية البحث: يعتبر الآدروبين هرمونا بيتيدا ويلعب دودا مهما في توانن الطا قة ووظائف بطانة الآوعية الدموية. آكسيد النيتريك هو عامل

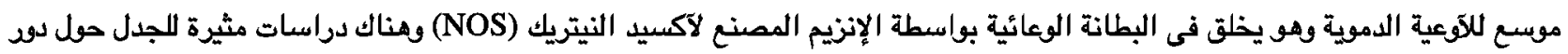

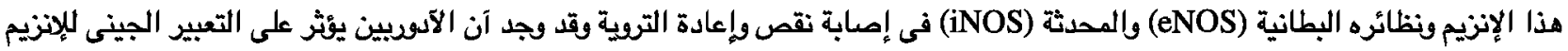

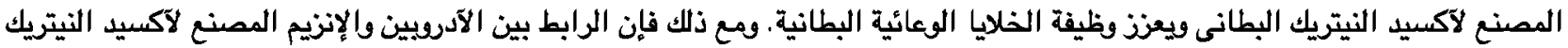

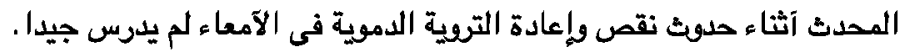

الهدف من البحث: تقدير مستوى الآدروبين والإنزيم المصنع لآكسيد النيتريك المحدث في البلازما ودراسة علاقة كل منهما ودوده خلال المراحل المختلفة لنقص وإعادة التروية الدموية فى آمعاء الجرذان.

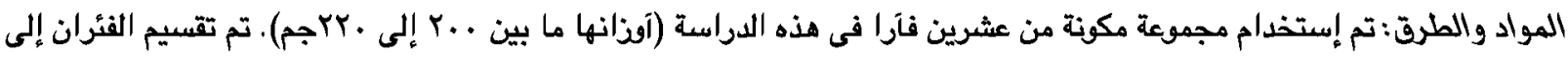

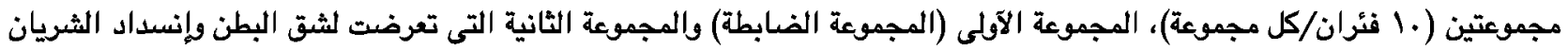

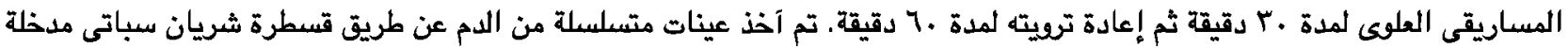

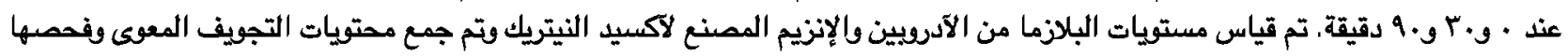

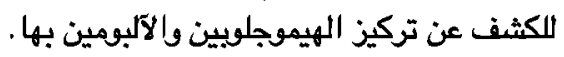

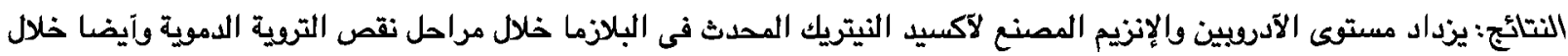

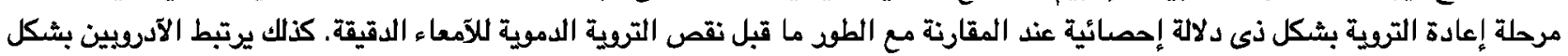

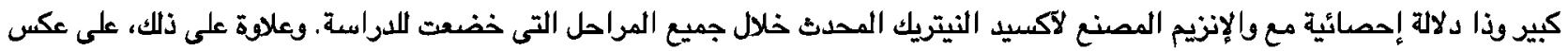
الآدروبين، إرتبط مستوى والإنزيم المصنع لآكسيد النيتريك المحدث مع شدة نزيف الآنيف الآمعاء.

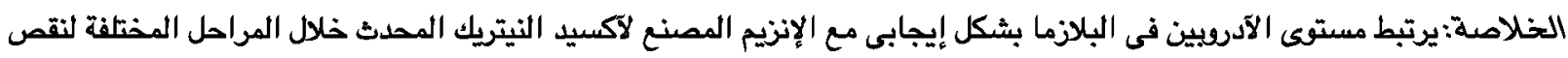

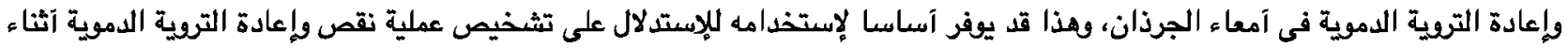
الجراحات المعوية. 